\title{
Synthesis of Dipalmitoyl
}

\section{Lecithin by Alveolar Macrophages}

\author{
Robert J. Mason, Gary Huber, and Martha Vaughan \\ From the Molecular Disease Branch, National Heart and Lung Institute, \\ National Institutes of Health, Bethesda, Maryland 20014, and The Channing \\ Laboratory, Harvard Medical Unit, Boston City Hospital, \\ Boston, Massachusetts 02118
}

A в S T R A C т A reliable, relatively simple method for isolation and quantification of disaturated lecithins is described. In rabbit lung, $34 \%$ of the lecithins were disaturated, in alveolar macrophages, $19 \%$. More than $95 \%$ of the fatty acids of the disaturated lecithins from lung and alveolar macrophages was palmitic. Hence, the disaturated lecithins from these sources were essentially all dipalmitoyl lecithin.

Both heterophils and alveolar macrophages incorporated ${ }^{14} \mathrm{C}$-labeled choline and palmitate into disaturated lecithins. Liver slices in which only about $1 \%$ of the lecithins were disaturated incorporated very little of these precursors into this fraction. Of the palmitate incorporated in vitro into disaturated lecithins by alveolar macrophages, heterophils, and lung slices, $37 \%$ was in the 1 position. In disaturated lecithins isolated from pulmonary lavage fluid, alveolar macrophages, and lung of rabbit $8-12 \mathrm{hr}$ after a single intravenous injection of palmitic- $1-{ }^{14} \mathrm{C}$ acid, $45 \%$ of the ${ }^{14} \mathrm{C}$ was in position 1 . At earlier times, from $20-240 \mathrm{~min}$ after injection, the distribution of ${ }^{14} \mathrm{C}$ was similar in the samples from lung, but in those from alveolar macrophages and lavage fluid, the percentage in position 1 was slightly lower.

Glycerol- $\mathrm{U}-_{-}^{14} \mathrm{C}$ was incorporated into disaturated lecithins by alveolar macrophages and by lung slices in vitro. Both tissues incorporated very little label from ethanolamine or from methyl-labeled methionine into this fraction. All of the data are consistent with the view that alveolar macrophages synthesize dipalmitoyl lecithin via the cytidine diphosphate-choline pathway.

This work was presented in part at the 13th Annual Aspen Emphysema Conference, Aspen, Colorado, June 1970, and published in abstract form (J. Clin. Invest. 1970. 49: 62a.).

Dr. Mason's present address is Cardiovascular Research Institute, University of California, San Francisco, California 94122 .

Received for publication 16 June 1971 and in revised form 29 July 1971.

\section{INTRODUCTION}

Dipalmitoyl lecithin is believed to be the major surface active component of pulmonary surfactant $(1,2)$. In order to investigate the pathways of its biosynthesis, it is necessary to separate dipalmitoyl lecithin from the other lecithins present in tissues. We have developed a convenient and reliable procedure for isolating disaturated lecithins, and have studied the incorporation of radio-labeled potential precursors into this fraction by alveolar macrophages, which are the only type of lung cell that can be obtained in relatively homogeneous populations for studies of this type. As reported below, about $20 \%$ of the lecithins of alveolar macrophages are disaturated, essentially all dipalmitoyl. In these cells as in lung, the cytidine diphosphate (CDP) ${ }^{1}$-choline pathway appeared to be the major route of synthesis. Some studies were also carried out with heterophils (which constitute less than $10 \%$ of the cells in most preparations of alveolar macrophages), and with liver slices in which only about $1 \%$ of the lecithins are disaturated.

\section{METHODS}

Preparation and incubation of tissues. Tissues were obtained from white New Zealand rabbits (3-4 kg) of both sexes, which were sacrificed by an intravenous injection of sodium pentobarbital, $25 \mathrm{mg} / \mathrm{kg}$, followed by $35 \mathrm{ml}$ of air. Alveolar macrophages obtained by pulmonary lavage with $0.15 \mathrm{M} \mathrm{NaCl}$ solution were collected by centrifugation at $150 \mathrm{~g}$ at $4^{\circ} \mathrm{C}$ for $10 \mathrm{~min}$. They were dispersed in the incubation medium (see below) with a siliconized Pasteur pipette, filtered through silk screen, and collected again by centrifugation. Only preparations which contained more than $90 \%$ macrophages (differential count of Giemsa stained smear) were used. Confirmation of the purity of the alveolar macrophages and the absence of granular pneumonocytes was obtained by electron microscopic examination of a sample of cells from one of these preparations, using

${ }^{1}$ Abbreviations used in this paper: BHT, 2,6-di-tert-butylp-cresol ; CDP, cytidine diphosphate. 
techniques previously described (3). None of the 200 cells counted contained desmosomes or the lamellar bodies characteristic of granular pneumonocytes (Type II alveolar epithelial cells).

The heterophils (more than $90 \%$ pure) were obtained 16 $\mathrm{hr}$ after intraperitoneal injection of $70 \mathrm{ml}$ of autoclaved neutral sodium caseinate solution $(150 \mathrm{mg} / \mathrm{ml})$ (Difco Laboratories, Detroit, Mich.) and were washed once with medium before incubation (4). Slices of liver and lung from untreated animals were made using a Stadie-Riggs tissue slicer.

Cells or tissue slices (circa $200 \mathrm{mg}$ ) were incubated for $1 \mathrm{hr}$ at $37^{\circ} \mathrm{C}$ in $3 \mathrm{ml}$ of Krebs-Ringer phosphate medium,

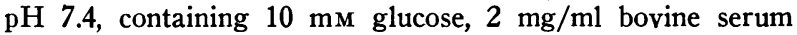
albumin (Fraction $\mathrm{V}$ from bovine serum, Armour Pharmaceutical Co., Chicago, Ill.), and a radioactive precursor. After addition of 3 volumes of chilled isotonic saline and centrifugation at $500 \mathrm{~g}$ for $5 \mathrm{~min}$, the medium was discarded and the sedimented tissue extracted as described below. (After incubation of alveolar macrophages for $1 \mathrm{hr}$ with palmitic- $1-{ }^{14} \mathrm{C}$ acid, the medium contained less than $1 \%$ of the total labeled disaturated lecithin.) Palmitic $-1-{ }^{14} \mathrm{C}$ acid (55 $\mathrm{mCi} / \mathrm{mmole})$, ethanolamine- $1,2{ }^{14} \mathrm{C}$ hydrochloride (1.5 $\mathrm{mCi} / \mathrm{mmole}$ ), choline- $1,2-{ }^{14} \mathrm{C}$ chloride $(5 \mathrm{mCi} / \mathrm{mmole})$, and glycerol-U $-{ }^{14} \mathrm{C}(8.4 \mathrm{mCi} / \mathrm{mmole})$ were obtained from $\mathrm{New}$ England Nuclear Corp., Boston, Mass. Choline-methyl- ${ }^{14} \mathrm{C}$ chloride $(54 \mathrm{mCi} / \mathrm{mmole})$ and $\mathrm{L}$-methionine-methyl ${ }^{14} \mathrm{C}(53.6$ $\mathrm{mCi} / \mathrm{mmole}$ ) were obtained from Amersham-Searle Corp., Arlington Heights, Ill. Palmitic $-1-{ }^{14} \mathrm{C}$ acid $(>96 \%$ of radioactivity in palmitate by gas-liquid chromatography) was complexed to defatted albumin (5). The final concentrations of added precursors were $1.9 \mu \mathrm{M}$ palmitate, $10 \mu \mathrm{M}$ choline, $0.9 \mu \mathrm{M}$ methyl-labeled choline, $111 \mu \mathrm{M}$ ethanolamine, $12 \mu \mathrm{M}$ glycerol, and $0.9 \mu \mathrm{M}$ methyl-labeled methionine. Choline- ${ }^{14} \mathrm{C}$-labeled lysolecithin was obtained by hydrolyzing murine liver lecithin $(96,000 \mathrm{cpm} / \mu$ mole $)$ with phospholipase A (6). The fatty acids of the labeled lysolecithin contained $0.6 \%$ myristic, $37.5 \%$ palmitic, $42.0 \%$ stearic, $16.2 \%$ oleic, and $3.7 \%$ linoleic acid.

In Vivo studies. Palmitic- $1-{ }^{14} \mathrm{C}$ acid or palmitic- $9,10-{ }^{8} \mathrm{H}$ acid $(200 \mathrm{mCi} / \mathrm{mmole}$ ) (New England Nuclear Corp., Boston, Mass.) (95\% of tritium in palmitate by gas-liquid chromatography) bound to albumin was injected into the marginal ear vein of six male rabbits. The amount, 10-400 $\mu \mathrm{Ci}$, varied with the time of sacrifice. After sacrifice and pulmonary lavage, pieces of lung were excised, washed with saline, and extracted. The lungs of the animal sacrificed at $20 \mathrm{~min}$ were perfused with saline and only the whitened areas analyzed. The pulmonary lavage fluid was centrifuged ( $250 \mathrm{~g}$ for $10 \mathrm{~min}$ ) at room temperature. The supernatant fluid was lyophilized, taken up in water, and extracted. The cell pellets were pooled and washed twice with 50 volumes of isotonic saline before extraction.

Lipid analyses. Samples of cells, tissue, or lavage fluid were extracted overnight at room temperature with chloroform-methanol $(2: 1, \mathrm{v} / \mathrm{v})$ containing $50 \mu \mathrm{g} / \mathrm{ml} \mathrm{BHT}(2,6-$ di-tert-butyl-p-cresol, Ionol, a gift from Shell Oil Company, New York). When phosphorus analyses were not performed, unlabeled lipids from rabbit lung were added to some samples of alveolar macrophages to facilitate visualization of lecithins on thin-layer plates. The phases were separated (7) using $100 \mathrm{~mm} \mathrm{KCl}$ or, when palmitic-1-14 $\mathrm{C}$ acid was present, $100 \mathrm{~mm} \mathrm{~K} \mathrm{~K}_{2} \mathrm{CO}_{3}$. The use of $\mathrm{K}_{2} \mathrm{CO}_{3}$ did not cause any detectable hydrolysis of disaturated lecithin. The lower phase was washed with $10 \mathrm{~mm}$ choline or etha- nolamine when the incubations contained choline $-{ }^{14} \mathrm{C}$ or ethanolamine $-{ }^{14} \mathrm{C}$.

Lecithins were isolated by chromatography on 250 micron Silica $\mathrm{H}$ plates (Analtech, Inc., Wilmington, Delaware) as described by Parker and Peterson (8). ${ }^{2}$ In most experiments, plates were exposed briefly to iodine vapor in order to visualize the lecithin fraction. The fatty acid composition and percentage disaturated lecithins of lung lecithins from plates exposed to iodine were not different from those of samples from plates sprayed with 2,7-dichlorofluoroscein. The lecithin areas were scraped into columns packed with glass wool and containing $2.5 \mathrm{ml}$ of chloroform, methanol, water, acetic acid, 50:50:2:1 (v/v). Columns were then washed with $2.5 \mathrm{ml}$ of the same mixture and three 2-ml portions of chloroform, methanol, water, $30: 50: 5(\mathrm{v} / \mathrm{v})$. In three experiments $98 \%$ of disaturated lecithins and $94 \%$ of mixed lecithins from liver were eluted by this procedure.

Saturated lecithins were separated by a modification of previously described methods $(2,10,11)$. The eluates were evaporated nearly to dryness under nitrogen at $35^{\circ} \mathrm{C} .3 \mathrm{ml}$ of theoretical lower phase (7) and $2 \mathrm{ml}$ of the upper phase were added. The solution was mixed, centrifuged, and the lower phase was evaporated to dryness. The lecithins were dissolved in $50 \mu \mathrm{l}$ of $\mathrm{CHCl}_{3}$ and adducted in 1 $\mathrm{ml}$ of a solution of mercuric acetate in methanol for 16 $\mathrm{hr}$ in the dark (12). Following addition of $2 \mathrm{ml}$ of chloroform, 2 drops acetic acid, and $0.75 \mathrm{ml}$ water, the solution was mixed and centrifuged. The upper phase containing excess mercuric acetate was discarded. The lower phase was washed three times with theoretical upper phase (7). (All excess mercuric acetate must be removed before chromatography.) Adducted lecithins were separated from the saturated lecithins by chromatography on Silica $\mathrm{H}$ plates with chloroform, methanol, $8 \mathrm{M} \mathrm{NH} \mathrm{OHH}_{4} 75: 25: 3.5$. Polyenoic, dienoic, and some of the monoenoic lecithins remained at the origin. Most of the monoenoic lecithins were found in a band that migrated more slowly than the saturated lecithins and was clearly separated from them. In eight samples of nonadducted lecithins isolated in this way, $96-100 \%$ of the fatty acids were saturated. After mixing with liver lecithins, over $90 \%$ of added dipalmitoyl lecithin could be isolated and recovered by this procedure.

In experiments such as that shown in Fig. 1, disaturated lecithin $-{ }^{3} \mathrm{H}(28.4 \mathrm{Ci} / \mathrm{mmole})$ was added to samples at the time of extraction of lipids from tissue, and values for disaturated lecithin were corrected on the basis of its recovery. For this purpose, egg lecithin (Type D-E, Sigma Chemical Co., St. Louis, Mo.) was reacted with tritium gas (New England Nuclear Corp., Boston, Mass), and the disaturated lecithins purified as described above.

Degradation of isolated disaturated lecithins with phospholipase A (Crotalus adamanteus venom, Sigma Chemical Co.) was carried out at least in duplicate $(6,13)$. Radioactivity in fatty acids, lecithin, and lysolecithin separated by thin-layer chromatography (8) was determined before and after incubation with venom.

Other materials and methods. All solvents were reagent grade (J. T. Baker Chemical Co., Phillipsburg, N. J.) and those used to prepare samples for gas-liquid chromatography were redistilled in an all-glass apparatus. The procedure for making the methyl esters of the fatty acids and

${ }^{2}$ In a sample of lecithin isolated by this procedure from alveolar macrophages incubated with palmitic- $1-{ }^{14} \mathrm{C}$ acid, over $95 \%$ of the radioactivity was in lecithin and less than $2 \%$ in palmitoyl carnitine (9). 


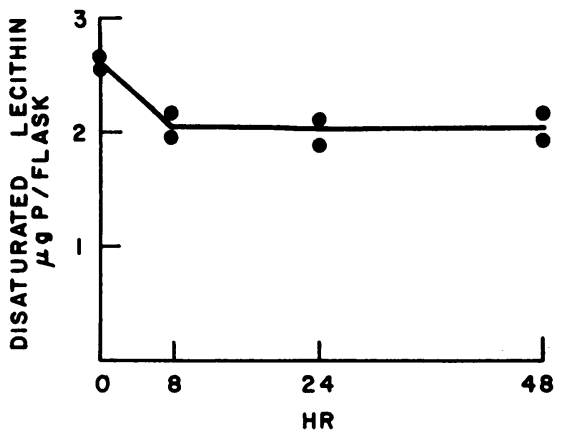

FIgURE 1 Alveolar macrophages in tissue culture. Cells were distributed in $150-\mathrm{cm}^{2}$ Petrie dishes and incubated for $2 \mathrm{hr}$. with McCoy's 5A medium, $10 \%$ fetal calf serum, penicillin $\mathrm{G}, 100 \mathrm{U} / \mathrm{ml}$, and streptomycin sulfate, $100 \mu \mathrm{g} /$ $\mathrm{ml}$. The nonadherent cells were removed by washing with phosphate buffered saline, $\mathrm{pH} 7.4$, fresh medium was added, and the dishes incubated for the indicated time before extraction of cells plus medium. Each point represents the value from one dish corrected for recovery of tritiated disaturated lecithin which was added during the extraction with chloroform-methanol (7).

the conditions for gas-liquid chromatography have been previously described (3). Phosphorus was determined by the method of Bartlett (14). Protein was measured by the method of Lowry, Rosebrough, Farr, and Randall (15) with bovine serum albumin as a standard. Supplies used for tissue culture included McCoy's medium 5A (National Institutes of Health Media Unit), fetal calf serum (Microbiological Associates, Inc., Bethesda, Md.), and $150 \mathrm{~cm}^{2}$ Petrie dishes (Falcon Plastics, Los Angeles, Calif.). Radioactivity of the isolated lecithin fractions was determined by scraping the silica from the thin-layer plates into counting vials and adding dioxane-naphthalene-water scintillation fluid (16). Lecithin $\left({ }^{8} \mathrm{H}\right.$ or $\left.{ }^{14} \mathrm{C}\right)$, lysolecithin $\left({ }^{14} \mathrm{C}\right)$, and palmitic acid $\left({ }^{8} \mathrm{H}\right.$ or $\left.{ }^{11} \mathrm{C}\right)$ were completely eluted from silica under these conditions.

\section{RESULTS}

Alveolar macrophages and lung contained considerably more disaturated lecithins per milligrams of protein than did heterophils or liver (Table I). In lung, $34.2 \pm 0.8 \%$
TABLE I

Phospholipid Content of Tissues

\begin{tabular}{lrrr}
\hline \multicolumn{1}{c}{ Tissue } & Phospholipids & $\begin{array}{c}\text { Total } \\
\text { lecithins }\end{array}$ & $\begin{array}{c}\text { Disaturated } \\
\text { lecithins }\end{array}$ \\
\hline & & $\mu g P / m g$ protein \\
Alveolar & & & \\
$\quad$ macrophages & $12.74 \pm 0.54$ & $4.68 \pm 0.19$ & $1.06 \pm 0.02$ \\
$\begin{array}{l}\text { Lung } \\
\text { Heterophils }\end{array}$ & $7.88 \pm 0.57$ & $3.88 \pm 0.26$ & $1.48 \pm 0.11$ \\
$\quad(W B C)$ & $3.76 \pm 0.29$ & $1.33 \pm 0.08$ & $0.22 \pm 0.01$ \\
Liver & $6.21 \pm 0.29$ & $2.95 \pm 0.16$ & $0.06 \pm 0.01$ \\
\end{tabular}

The values are the mean $\pm \mathrm{SE}$ for analyses of tissues from three rabbits. These values were calculated from the percentage of the total lipid phosphorus that was lecithin (8) and the percentage of the lecithin that was disaturated for each sample.

(mean $\pm \mathrm{SE}, \mathrm{n}=10$ ) of the total lecithins were disaturated; in alveolar macrophages $18.9 \pm 1.4 \%(n=8)$, in heterophils $15.8 \pm 0.5 \%(\mathrm{n}=5)$, and in liver only 1.3 $\pm 0.2 \%(\mathrm{n}=9)$. More than $95 \%$ of the fatty acids of the disaturated lecithins from alveolar macrophages and lung was palmitic. Hence, the disaturated lecithins from these sources were essentially all dipalmitoyl lecithin.

As shown in Table II, all of the tissues incorporated both palmitic-1 $-{ }^{14} \mathrm{C}$ acid and choline- $1,2-{ }^{14} \mathrm{C}$ into disaturated lecithins. Incorporation of methyl-labeled choline was comparable to that of the 1,2-labeled compound (data not shown). Alveolar macrophages incorporated more palmitate $-{ }^{14} \mathrm{C}$ and choline $-{ }^{14} \mathrm{C}$ per $\mu \mathrm{g}$ lipid phosphorous into all lecithins than did heterophils. For each precursor, however, incorporation into disaturated lecithins as a fraction of incorporation into total lecithins was about the same in the two types of cells. Similarly, in lung slices approximaately $40 \%$ of the palmitate incorporated into lecithins was in the disaturated fraction and $14 \%$ of the choline. In liver slices, on the other hand, disaturated lecithins contained only about

TABLE II

Incorporation of Precursors into Lecithins In Vitro

\begin{tabular}{|c|c|c|c|c|c|c|c|c|}
\hline \multirow[b]{2}{*}{ Tissue } & \multicolumn{3}{|c|}{ Palmitic-1-14C acid } & \multicolumn{3}{|c|}{ Choline-1,2-14 C } & \multicolumn{2}{|c|}{ Glycerol-U-14C } \\
\hline & & otal & Disaturated & & tal & Disaturated & Total & Disaturated \\
\hline & \multicolumn{8}{|c|}{ cpm/ $/ \mu g$ lipid $P / h r$} \\
\hline $\begin{array}{l}\text { Alveolar } \\
\text { macrophages }\end{array}$ & 57.6 & \pm 9.9 & $22.8 \pm 3.7(4)$ & 286 & \pm 43 & $34.9 \pm 0.6(2)$ & $44.2 \pm 8.4$ & $11.5 \pm 2.8(3)$ \\
\hline Heterophils & 27.6 & \pm 2.5 & $14.3 \pm 1.9$ & 52.2 & & 7.47 (1) & & \\
\hline Lung & 16.3 & \pm 3.8 & $6.6 \pm 1.5$ & 22.6 & \pm 7.8 & $3.23 \pm 1.12(2)$ & $5.48 \pm 0.44$ & $1.25 \pm 0.11(2)$ \\
\hline Liver & 1.19 & \pm 0.11 & $0.15 \pm 0.02$ & 1.30 & \pm 0.18 & $0.07 \pm 0.01(2)$ & & \\
\hline
\end{tabular}

The number of tissue samples studied (from different animals) is listed in parentheses following the value for disaturated lecithin. Each determination was done at least in duplicate. The values are the mean $\pm \mathrm{SE}$ or one half the range if the number of animals is less than three. 
TABLE III

Incorporation of 1-Acyl-2-Lysolecithin-14C into Lecithins In Vitro

\begin{tabular}{lcc}
\hline \multicolumn{1}{c}{ Tissue } & Total & Disaturated \\
lecithins & \multicolumn{2}{c}{$c p m / \mu g$ lipid $P / h r$} \\
\hline & \multicolumn{2}{c}{$c$ leciths } \\
Alveolar macrophages & $28.07 \pm 5.12$ & $1.14 \pm 0.13$ \\
Heterophils & $77.90 \pm 9.20$ & $9.53 \pm 1.00$ \\
\hline
\end{tabular}

Cells were incubated for $1 \mathrm{hr}$ in medium containing $0.5 \mathrm{mM}$ 1-acyl-2-lysolecithin- ${ }^{14} \mathrm{C}$ and albumin, $30 \mathrm{mg} / \mathrm{ml}$. The values are the means \pm SE for samples of alveolar macrophages from four rabbits and heterophils from three.

$13 \%$ of the palmitate- ${ }^{14} \mathrm{C}$ and $5 \%$ of the choline $-{ }^{14} \mathrm{C}$ of the total lecithins.

Alveolar macrophages and lung also incorporated glycerol-U- ${ }^{14} \mathrm{C}$ into lecithins, and about $25 \%$ of it was in the disaturated fraction. Lung slices, alveolar macrophages, and heterophils incorporated very little L-methionine-methyl- ${ }^{14} \mathrm{C}(1-\mathrm{hr}$ incubation) or ethanolamine-1,2${ }^{14} \mathrm{C}$ (3-hr incubation) into lecithins. In alveolar macrophages, $95 \%$ of the label that was incorporated was in unsaturated lecithins. Liver slices incorporated L-methionine-methyl $-{ }^{14} \mathrm{C}$ more actively than other tissues, and essentially all the label was in the unsaturated lecithins (data not shown). As shown in Table III and previously reported (17), alveolar macrophages incorporated less than one third as much lysolecithin into lecithins as did heterophils. In the latter cells, about $12 \%$ of that incorporated was recovered in the disaturated fraction, in the alveolar macrophages about $5 \%$.

Disaturated lecithins isolated from cells incubated with palmitate-1 $-{ }^{14} \mathrm{C}$ were hydrolyzed with phospholipase $\mathrm{A}$, and the radioactivity in the 1 and 2 positions determined. In samples from macrophages, heterophils, and lung, $35-40 \%$ of the ${ }^{14} \mathrm{C}$ was in position 1 (Table IV). The distribution of radioactivity was not influenced by sex of the donor rabbits or by the time of incubation (15-90 min) (data not shown).

At several times from $20 \mathrm{~min}$ to $12 \mathrm{hr}$ after intravenous injection of labeled palmitic acid, the distribution of radioactivity in the extracellular disaturated lecithins of pulmonary lavage fluid was compared with that of alveolar macrophages and of whole lung. As shown in Table $\mathrm{V}$, at early times almost $50 \%$ of the label in the lecithins from lung was in the 1 position, whereas in the macrophage and lavage fluid samples $40 \%$ or less was in this position. At later times, when the specific activities of the macrophage and lavage fluid disaturated lecithins were higher, the distribution of labeled fatty acids in these samples was not different from that in the lung disaturated lecithins, i.e., in all samples about $45 \%$ was in the 1 position.
TABLE IV

Distribution of Palmitic-1.14C Acid Incorporated In Vitro into Disaturated Lecithins

\begin{tabular}{lc}
\hline \multicolumn{1}{c}{ Tissue } & $\begin{array}{c}\text { Amount } \\
\text { of } 14 \mathrm{C} \text { in } \\
\text { position } 1\end{array}$ \\
\hline & $\%$ \\
Alveolar macrophages (7) & $38.7 \pm 1.9$ \\
"Pure" alveolar macrophages* (4) & $36.2 \pm 0.8$ \\
Heterophils (3) & $35.7 \pm 0.9$ \\
Lung (6) & $35.7 \pm 2.5$ \\
\hline
\end{tabular}

The values are the mean $\pm \mathrm{SE}$ for the number of samples of each tissue (from different animals) shown in parentheses. All determinations were done at least in duplicate. Position 1 is the alpha position in other nomenclature (30).

* Suspensions consisting of $>\mathbf{9 8 \%}$ alveolar macrophages were prepared as described by Hurst, Gardner, and Coffin (31).

Several unsuccessful attempts were made to demonstrate accumulation of disaturated lecithins in alveolar macrophages incubated under tissue culture conditions. Different types of medium, different lots and concentrations of fetal calf serum, and different surfaces for growth were used. The initial drop in total disaturated lecithins (Fig. 1) was seen in all experiments including those in which cells only were analyzed, and is consistent with the known ability of these cells to hydrolyze lecithins (18).

\section{DISCUSSION}

All of our data are consistent with the view that alveolar macrophages and lung synthesize dipalmitoyl lecithin via the CDP-choline pathway. In the lung of the adult rabbit we found, as reported earlier by others (19, 20 ), very little incorporation of label from L-methioninemethyl ${ }^{14} \mathrm{C}$ or ethanolamine- $1,2{ }^{14} \mathrm{C}$ into any type of lecithin in vitro. Alveolar macrophages also incorporated only small amounts of these precursors into lecithins, and

\section{TABLE V}

Distribution of Palmitic-1-14C Acid Incorporated In Vivo into Disaturated Lecithins

\begin{tabular}{llllllll}
\hline & \multicolumn{6}{c}{ Amount $14 \mathrm{C}$ in position 1 } \\
\cline { 2 - 7 } \multicolumn{1}{c}{ Tissue } & \multicolumn{6}{c}{ Sampling time, min after injection } \\
\cline { 2 - 7 } \multicolumn{1}{c}{} & 20 & 60 & 120 & 240 & 480 & 720 \\
\hline Lung & 49 & 47 & 44 & 43 & 45 & 44 \\
Lavage fluid & - & 32 & 37 & 35 & 44 & 44 \\
Alveolar macrophage & - & 32 & 40 & - & 43 & 48 \\
\hline
\end{tabular}

Each value represents the mean of duplicate analyses of a sample from one rabbit. 
$95 \%$ of that was in unsaturated lecithins. Thus, there was little evidence for synthesis of disaturated lecithins by methylation of phosphatidyl ethanolamine. The demonstrated incorporation of glycerol- $\mathrm{U}_{-}{ }^{14} \mathrm{C}$ and of choline-1,2- ${ }^{14} \mathrm{C}$ into disaturated lecithins by alveolar macrophages and lung would appear to be good evidence for de novo synthesis, but does not exclude the possibility that newly synthesized unsaturated lecithins were rapidly modified to yield disaturated lecithins. ${ }^{3}$ The observed distribution of palmitic acid $-{ }^{14} \mathrm{C}$ incorporated into disaturated lecithins in vitro is consistent with this interpretation. In disaturated lecithins isolated from rabbit lung 20-720 min after intravenous administration of the precursor, palmitic- $1-{ }^{14} \mathrm{C}$ acid was almost equally distributed between the 1 and 2 positions. The distribution was similar in the saturated lecithins of alveolar macrophages and lavage fluid after $4 \mathrm{hr}$. At earlier times when these latter fractions contained smaller amounts of palmitate- ${ }^{14} \mathrm{C}$ (22) there appeared to be a preponderance of label in the 2 position, which could be due to acylation of 1 -acyl2-lysolecithin formed from preexisting lecithins. It has recently been reported that microsomes from dog lung catalyze the acylation of both 1- and 2-lysolecithins (23). The demonstrated incorporation of exogenous 1-acyl-2lysolecithin into lecithins by alveolar macrophages presumably resulted from acylation since Elsbach (18) found no evidence for synthesis of lecithins by transesterification of lysolecithin in alveolar macrophages.

Because alveolar macrophages can be studied in populations essentially free of other types of cells, it has been possible to designate for the first time at least one specific type of cell from lung that contains dipalmitoyl lecithin in relatively large amounts and can synthesize it. Although the concentration (per milligram protein) of disaturated lecithin in heterophils is only about $20 \%$ of that in alveolar macrophages, it is considerably higher than the concentration in many other types of cells (e.g. liver), and the percentage of total lecithin that is disaturated is quite similar in heterophils and macrophages. One wonders whether the disaturated lecithin in these two types of cells is in some way related to their phagocytic function. The role of alveolar macrophages in the production of dipalmitoyl lecithin for pulmonary surfactant remains to be evaluated. Although there are ultrastructural $(24)$ and histochemical $(25,26)$ similarities between these cells and granular pneumonocytes which are believed to be the source of pulmonary surfactant $(27,28)$, the relationship between the two types of cells is unclear (29). In order to investigate synthesis of dipalmitoyl lecithin by the Type II pneumonocytes, it will be necessary to devise methods for separating these cells from other types present in lung.

\footnotetext{
${ }^{3}$ The extent to which choline might be incorporated by base exchange (21) was not evaluated.
}

\section{ACKNOWLEDGMENTS}

We thank Doctors J. Clement, R. King, V. Manganiello, and T. Stossel for valuable suggestions, Dr. H. Sloan for ${ }^{14} \mathrm{C}$-labeled murine liver lecithin, Dr. R. Bressler for palmitoyl carnitine, and Mr. W. Thompson for technical assistance.

\section{REFERENCES}

1. Brown, E. S. 1964. Isolation and assay of dipalmitoyl lecithin in lung extracts. Amer. J. Physiol. 207: 402.

2. Clements, J. A., J. Nellenbogen, and H. J. Trahan. 1970. Pulmonary surfactant and evolution of the lungs. Science (Washington). 169: 603.

3. Huber, G. L., R. J. Mason, F. M. LaForce, N. J. Spencer, G. E. Gardner, and D. L. Coffin. 1971. Alterations in the lung following the administration of ozone. Arch. Intern. Med. 128: 81 .

4. Stossel, T. P., F. Murad, R. J. Mason, and M. Vaughan. 1970. Regulation of glycogen metabolism in polymorphonuclear leukocytes. J. Biol. Chem. 245: 6228.

5. Spector, A., D. Steinberg, and A. Tanaka. 1965. Uptake of free fatty acids by Ehrlich ascites tumor cells. J. Biol. Chem. 240: 1032.

6. Long, C., and I. F. Penny. 1957. The structure of the naturally occurring phosphoglycerides. Biochem. J. 65: 382.

7. Folch, J., M. Lees, and G. H. Sloane-Stanley. 1957. A simple method for the isolation and purification of total lipids from animal tissues. J. Biol. Chem. 226: 497.

8. Parker, F., and R. F. Peterson. 1965. Quantitative analysis of phospholipid and phospholipid fatty acids from silica gel thin-layer chromatograms. J. Lipid Res. 6: 455.

9. Wittels, B., and R. Bressler. 1965. Two dimensional thin-layer chromatographic isolation of fatty acyl carnitines. J. Lipid Res. 6: 313.

10. Blank, M. L., L. J. Nutter, and O. S. Privett. 1966. Determination of the structure of lecithins. Lipids. 1: 132.

11. Morgan, T. E., and L. H. Edmunds, Jr. 1967. Pulmonary artery occlusion. III. Biochemical alterations. $J$. Appl. Physiol. 22 : 1012.

12. Mangold, H. K. 1961. Thin-layer chromatography of lipids. J. Amer. Oil Chem. Soc. 38: 708.

13. Hanahan, D. J., M. Rodbell, and L. D. Turner. 1954. Enzymatic formation of monopalmitoleyl and monopalmitoyl lecithin (lysolecithins). J. Biol. Chem. 206: 431.

14. Bartlett, G. R. 1959. Phosphorus assay in column chromatography. J. Biol. Chem. 234: 466.

15. Lowry, O. H., N. J. Rosebrough, A. L. Farr, and R. J. Randall. 1951. Protein measurement with the Folin phenol reagent. J. Biol. Chem. 193: 265.

16. Snyder, F. 1964. Radioassay of thin-layer chromatograms: a high-resolution zonal scraper for quantitative $\mathrm{C}^{14}$ and $\mathrm{H}^{3}$ scanning of thin-layer chromatograms. Anal. Biochem. 9: 183.

17. Elsbach, P. 1968. Increased synthesis of phospholipid during phagocytosis. J. Clin. Invest. 47: 2217.

18. Elsbach, P. 1966. Phospholipid metabolism by phagocytic cells. I. A comparison of conversion of ${ }^{32} \mathrm{P}-1$ ysolecithin to lecithin and glycerylphosphorylcholine by homogenates of rabbit polymorphonuclear leukocytes and alveolar macrophages. Biochim. Biophys. Acta. 125: 510.

19. Gluck, L., M. Sribney, and M. V. Kulovich. 1967. The biochemical development of surface activity in mammalian lung. II. The biosynthesis of phospholipids in 
the lung of the developing rabbit fetus and newborn. Pediat. Res. 1: 247.

20. Spitzer, H. L., K. Morrison, and J. R. Norman. 1968. The incorporation of $\mathrm{L}-\left(\mathrm{Me}-{ }^{14} \mathrm{C}\right)$-methionine and $(\mathrm{Me}-$ $\left.{ }^{3} \mathrm{H}\right)$-choline into lung phosphatides. Biochim. Biophys. Acta. 152: 552.

21. Treble, D. H., S. Frumkin, J. A. Gaunt, and D. A. Beeler. 1970. The entry of choline into lecithin in vivo by base exchange. Biochim. Biophys. Acta. 202: 163.

22. Young, S., and D. F. Tierney. 1970. Kinetics of dipalmitoyl lecithin secretion onto the surface of the rat lung. Clin. Res. 18: 192.

23. Frosolono, M. F., S. Slivka, and B. L. Charms. 1971. Acyl transferase activities in dog lung microsomes. $J$. Lipid Res. 12: 96.

24. Karrer, H. E. 1958. The ultrastructure of mouse lung: the alveolar macrophage. J. Biophys. Biochem. Cytol. 4: 693 .

25. Azzopardi, A., and W. M. Thurlbeck. 1967. The oxidative enzyme pattern in developing adult mice and adult rabbits. Lab. Invest. 16: 706.
26. Said, S. I., R. M. Klein, L. W. Norrell, and Y. T. Maddox. 1966. Metabolism of alveolar cells: histochemical evidence and relation to pulmonary surfactant. Science (Washington). 152: 657.

27. Buckingham, S., H. O. Heinemann, S. C. Sommers, and W. F. McNary. 1966. Phospholipid synthesis in the large pulmonary alveolar cell. Amer. J. Pathol. 48: 1027.

28. Buckingham, S., and M. E. Avery. 1962. Time of appearance of lung surfactant in the fetal mouse. Nature (London). 193: 688.

29. Sorokin, S. P. 1966. A morphologic and cytochemical study on the great alveolar cell. J. Histochem. Cytochem. 14: 884 .

30. IUPAC-IUB Commission on Biochemical Nomenclature. 1968. The nomenclature of lipids. Biochim. Biophys. Acta. $152: 1$.

31. Hurst, D. J., D. E. Gardner, and D. L. Coffin. 1970. The effect of ozone on acid hydrolases of the pulmonary alveolar macrophage. J. Reticuloendothel. Soc. 8: 288. 